\title{
SERVICE AT THE FORTRESS OF TSARITSYN AND TSARITSYN SERVICE PEOPLE IN THE ACCOUNT BOOKS OF THE TREASURY COURT. 1615/16-1621/22
}

\author{
Alexandr V. Malov \\ Institute of Russian History, RAS, Moscow, Russian Federation
}

\begin{abstract}
Introduction. The article is devoted to the first mention of people and events related to the fortress of Tsaritsyn restored in 1615 in the account books of the treasury court, starting with the first mention and up to 1622. Methods and materials. In total, the account books of the treasury court kept records of 36 cases of granting fabrics for the outlined period. These records on services at the fortress contain the names of 72 servicemen including: voivode, 8 boyar's children, 2 colonels, 5 sotniks and 25 Tsaritsyn streltsy, 8 Tsaritsyn pathfinders. According to published materials of the Order-in-charge Prikaz, the paper analyzes the dynamics of Tsaritsyn garrison restoration correlating with the data of account records. Analysis. The analysis of systemized records from September 1619 shows that the Tsaritsyn garrison was fully restored after the restoration of the fortress and was able to defend not only the fortress, but also the entire territory controlled by it. The garrison carried out all the basic functions to combat the Cossack robberies on the Volga and cleared areas of steppe roads situated on the West and East of Tsaritsyn from the Azov, Nagai and Cossack robbers. Results. As a result, the study introduces a valuable set of written sources into scientific use, which made it possible to clarify a whole range of issues and problems of the early history of Tsaritsyn.

Key words: the Time of Troubles, the Lower Volga Region, Tsaritsin, service people, treasury court, consequences of the Time of Troubles.

Citation. Malov A.V. Service at the Fortress of Tsaritsyn and Tsaritsyn Service People in the Account Books of the Treasury Court. 1615/16-1621/22. Vestnik Volgogradskogo gosudarstvennogo universiteta. Seriya 4, Istoriya. Regionovedenie. Mezhdunarodnye otnosheniya [Science Journal of Volgograd State University. History. Area Studies. International Relations], 2019, vol. 24, no. 2, pp. 184-202. (in Russian). DOI: https://doi.org/10.15688/ jvolsu4.2019.2.16
\end{abstract}

\section{ЦАРИЦЫНСКИЕ СЛУЖБЫ И ЦАРИЦЫНСКИЕ СЛУЖИЛЫЕ ЛЮДИ В РАСХОДНЫХ КНИГАХ КАЗЕННОГО ДВОРА. 124-й (1615/16) - 130-й (1621/22) ГОДЫ}

\author{
Александр Витальевич Малов \\ Институт российской истории РАН, г. Москва, Российская Федерация
}

\begin{abstract}
Аннотация. Введение. Статья посвящена первым упоминаниям в расходных книгах Казенного двора людей и событий, связанных с восстановленным в 1614-1616 гг. Царицыным в конце Смуты, начиная с первого упоминания и до разбора служилых городов в 130-м (1621/22) году. Meтоды и материальl. Всего за ‥ очерченный период расходные книги Казенного двора сохранили записи 36 случаев пожалования тканями. В этих записях о царицынских службах поименованы 72 служилых человека, в том числе: воевода, 8 детей боярских, 2 головы, 5 сотников и 25 царицынских стрельцов, 8 царицынских вожей. По опубликованным материалам Разрядного приказа проанализирована динамика восстановления гарнизона Царицына, с которой соотнесены данные расходных записей. Анализ. Анализ систематизированных записей с сентября 1619 г.

показывает, что гарнизон Царицына следом за крепостью был вполне восстановлен и способен оборонять
\end{abstract}


не только крепость, но и всю подконтрольную этой крепости территорию, осуществляя все основные функции по борьбе с казачьими разбоями на Волге и очищая от азовских, нагайских и казачьих грабителей подходящие к Царицыну с запада и востока участки степных дорог. Результаты. В результате проведенного исследования в научный оборот введен ценный комплекс источников, позволивший восполнить имевшиеся пробелы в ранней истории Царицына.

Ключевые слова: Смутное время, Нижняя Волга, Царицын, служилые люди, Казенный двор, последствия Смуты.

Цитирование. Малов А. В. Царицынские службы и царицынские служилые люди в расходных книгах Казенного двора. 124-й (1615/16) - 130-й (1621/22) годы // Вестник Волгоградского государственного университета. Серия 4, История. Регионоведение. Международные отношения. - 2019. - Т. 24, № 2. - С. 184-202. - DOI: https://doi.org/10.15688/jvolsu4.2019.2.16

Введение. Предлагаемая вниманию читателей статья посвящена ранним сведениям в расходных книгах Казенного двора ${ }^{1}$ о людях и событиях, связанных с восстановленным в 123 (1614/15) - 124-м (1615/16) гг. Царицыным в конце Смуты, начиная с первого упоминания и до разбора служилых городов в 130-м (1621/22) году.

Методы и материалы. Заговор и переворот в Москве, закончившиеся убийством Лжедмитрия I и воцарением Василия Ивановича Шуйского, вывели развитие Смуты на новый виток. В этот период Царицын на несколько лет исчезает из всех документов, когда у историков нет данных для утверждения о существовании его не только как города, но вообще населенного пункта. Предшествующие информационному провалу упоминания связаны с действиями на Волге войска Федора Ивановича Шереметева, когда ему не удалось взять Астрахань. Героическое сидение Ф.И. Шереметева с товарищем Иваном Дмитриевичем Зайкой Плещеевым на острове Балчике продолжалось до октября 1607 года. Пока Шереметев стоял на Балчике, видимо, мимо него степями на Терек прошли посланные за самозванцем Иван Никитич Салтыков и Федор Степанов сын Лихарев Пусторжевец с головами [4, с. 86, 142, 179 , $184 ; 35$, с. $133 ; 40$, s. $324^{2}$ ].

Летом 1607 г. очередной самозванец Иван-Август взял Царицын и убил его воеводу Ф.П. Чудинова-Акинфова, перерезав Шереметеву связь с Казанью [35, с. 76, 132]. В октябре 1607 г. Шереметев ушел с Балчика из-под Астрахани к Царицыну [38, с. 29; 39, с. 216-220]. Воеводы царя Василия отошли от Астрахани вверх по Волге и атаковали ее северный форпост - крепость Царицын
[37, с. 132-147; 30, с. 6]. Здесь, «как боярин пошел вверх под Царицын, и город Царицын взятьем взял», его ратные люди были «на приступе», и «языки имали», и «на Царицыне были» [2, с. 308-336], «Царицын город и острог взяли и государевых изменников побили и поимали» [33, с. 170]. Всех переживших штурм и не разбежавшихся защитников Царицына привели к присяге на имя царя Василия. Укрепившись и просидев на Царицыне около года, Шереметев где-то в конце лета начале осени получил приказ о скорейшем прибытии к Москве [35, с. 263-264]. В октябре 1608 г., вероятно дождавшись также отозванных к Москве терских воевод Ивана Никитича Салтыкова и Федора Степанова сына Лихарева Пусторжевца с их терским отрядом, Шереметев увел из Царицына свое войско в Казань, куда прибыл в середине ноября [38, с. $29 ; 39$, с. 216-220; 35, с. 308]. Понимая, что после ухода его армии удержать Царицын, как и Саратов, через который проходила армия, не удастся, Шереметев сжег крепости обоих городов, забрав с собой присягнувшие Василию Шуйскому части гарнизонов обоих городов [37, с. 140-141; 30, с. 6-7]. Конечно, воеводы должны были вывезти из этих городов в Казань всю артиллерию и боеприпасы.

В том же октябре 1608 г. Царицын вновь перешел на сторону Тушинского вора [39, c. 229]. Именно это сообщение считалось последним перед восстановлением здесь центральной власти уже царя Михаила Федоровича Романова [6, с. 196-197], пока И.О. Тюменцев не нашел упоминания о контактах царицынцев с Тушиным в 1609 г. [37, с. 141]. Данный факт является единственным свидетельством продолжения существования по- 


\section{ИСТОРИЯ СМУТНОГО ВРЕМЕНИ}

селения на месте города. Сведения о восстановлении здесь центральной власти напрямую связаны со строительством города Царицына в 123-м (1614/15) - 124-м (1615/ 16) $\left[6\right.$, с. $199-200 ; 15$, стб. 196 ${ }^{3}$ гг., когда разрядные записи зафиксировали здесь царского воеводу Мисюря (в иночестве - Пантелея) Иванова (Головина) сына Соловцова. Правда, единичность упоминания Соловцова в Царицыне в 123-м (1614/15) г. в Дворцовых разрядах [8, стб. 193] требует поставить вопрос об ошибке записи, но за отсутствием надежных источников pro et contra будем исходить из того, что именно в этом году и был «наряжен» Соловцов в Царицын на строительство и воеводство. Несомненно, до восстановления Царицына у правительства «дошли руки» лишь после завершения астраханской кампании против И.М. Заруцкого и Марины Мнишек с «Воренком», когда их 24 июня 1614 г., наконец, захватили на Яике и отослали в Москву. До этого момента Царицын упоминался лишь раз в связи с отпуском задержанного со времен Василия Шуйского персидского посольства Амира Алибека (1608-1614 гг.) и отправки новым государем своего первого посольства в Иран Михаила Никитича Тиханова и дьяка Алексея Бухарова. Тогда в ноябре 1613 г. в Посольском приказе рассматривали два маршрута из России в Иран в обход Астрахани - один из них должен был начинаться от Царицына и «калмыцкими» (?) степями выходил на Терки, далее - на Тарки и Дербент. Однако в этом упоминании ничто не указывало на то, что речь идет не о топографической точке (какой была Царицынская сторожа до постройки города), а о населенном пункте.

Первые упоминания пожалованных на Казенном дворе служилых людей «за царицынский выход, и за службу, и за сеунчь» относятся к февралю 1616 г., а завершает рассматриваемый здесь хронологический период запись пожалования за царицынские службы 1620-1621 гг. против воровских казаков и азовских людей в августе 1622 года. Всего за очерченный период расходные книги Казенного двора (15 февраля 1622 г. Казенный двор был впервые назван Казенным приказом) сохранили записи 36 случаев пожалова- ния тканями - как правило сукном, в исключительных случаях дополняемые шелками ${ }^{4}$. В этих записях о царицынских службах поименованы 72 служилых человека, в том числе царицынские: воевода из нижегородцев, 3 царицынских сына боярских, 2 головы, 4 сотника и 25-30 царицынских стрельцов, до 8 царицынских вожей; из нецарицынских служилых: жилец или стряпчий из Москвы, казанский жилец, 2 алаторских и 2 курмышских детей боярских, сотник казанских стрельцов. Необходимо соотнести сведения расходных книг Казенного двора с первыми известными данными о составе, структуре и численности царицынского гарнизона, их устойчивости и динамике изменений за первые послесмутные годы - такую возможность предоставляют документы Разрядного приказа (разрядные книги и сметы).

Анализ. В период воеводства в Царицыне ${ }^{5}$ М.И. Соловцова (1615-1616), Ивана Остренева (1617-1618), Федора Васильевича Левашова (1619 - июль 1621), Ивана Юрьевича Нелединского (июль 1621-1622) и кн. Никиты Никитича Гагарина (1623-1624) разрядные книги не фиксировали состав и численность служилых людей на Царицыне [15, стб. 196, 406, 514, 663, 720, 764, 871, 926, 10331034]. Хотя, как минимум, при передаче воеводства несомненно должны были составляться росписи городу и написанных за ним служилых людей. Эти документы отсылались в приказ Казанского дворца, в архиве которого, вероятно, и сгорели. Сохранились лишь те данные, которые Казанский дворец по запросу Разряда отослал ему с памятью, что впервые случилось в 133-м (1624/25) году. Начиная с этого года, с воеводства в Царицыне Дмитрия Постникова сына Новосильцева, состав и численность царицынских служилых людей в Царицыне стали запрашивать из Разряда и вносить в разрядные книги [7, с. $73 ; 36$, c. 183-195]. Это вполне согласуется с наблюдениями В.И. Буганова над составом и содержанием официальных разрядных книг, структура которых постепенно складывается к 1620 г., а к 1627/28 г. вполне кодифицируется $[27$, с. 3]. Нагляднее состав, структуру, численность царицынского гарнизона и динамику изменений можно представить в таблице, а подробнее разобрать в комментариях. 
А.В. Малов. Царицынские службы и царицынские служилые люди в расходных книгах Казенного двора

Состав и численность служилых людей в Царицыне по разрядным книгам и сметным росписям за 1-ю половину XVII века

\begin{tabular}{|c|c|c|c|c|c|c|c|c|}
\hline Люди & 7133-7134 гг. & 7134-7136 гг. & 7136 г. & 7137 г. & $\begin{array}{c}7137 \text { г. } \\
\text { («Смета } \\
139-г о ») \\
\end{array}$ & 7138 г. & 7139 г. & \begin{tabular}{|c|}
$7138-7139$ гг. \\
(«Смета \\
1632 г.») \\
\end{tabular} \\
\hline Воевода & $\begin{array}{l}\text { Д.П. Ново- } \\
\text { сильцев }\end{array}$ & С.Ф. Глебов & $\begin{array}{l}\text { М.И. Зу- } \\
\text { бов } \\
\end{array}$ & $\begin{array}{l}\text { М.И. Зу- } \\
\text { бов }\end{array}$ & М.И. Зубов & $\begin{array}{c}\text { кн. Л.М. Вол- } \\
\text { конский } \\
\end{array}$ & $\begin{array}{c}\text { кн. Л.М. Вол- } \\
\text { конский } \\
\end{array}$ & $\begin{array}{c}\text { кн. Л.М. Вол- } \\
\text { конский } \\
\end{array}$ \\
\hline Подьячие & - & - & - & - & - & - & - & - \\
\hline $\begin{array}{l}\text { Дети бояр- } \\
\text { ские }\end{array}$ & 5 & 5 & 5 & 5 & 5 & 5 & 5 & 5 \\
\hline $\begin{array}{l}\text { Голова } \\
\text { стрелецкий }\end{array}$ & 1 & 1 & 1 & 1 & $\begin{array}{c}\text { Василий } \\
\text { Стромилов }\end{array}$ & - & - & 1 \\
\hline $\begin{array}{l}\text { Сотники } \\
\text { стрелецкие }\end{array}$ & 3 & 3 & 3 & 3 & 3 & 3 & 3 & 3 \\
\hline $\begin{array}{l}\text { Стрельцы } \\
\text { конные }\end{array}$ & \multirow[t]{2}{*}{350} & \multirow[t]{2}{*}{350} & 100 & 100 & 100 & 100 & 100 & 100 \\
\hline $\begin{array}{l}\text { Стрельцы } \\
\text { пешие }\end{array}$ & & & 200 & 200 & 200 & 200 & 200 & 200 \\
\hline Вожи & 3 & 3 & 3 & 3 & 3 & 3 & 3 & 3 \\
\hline Толмачи & 1 & 1 & 1 & 1 & 1 & 1 & 1 & 1 \\
\hline Пушкари & 4 & 4 & 4 & 4 & \multirow[t]{2}{*}{8} & \multirow[t]{2}{*}{8} & \multirow[t]{2}{*}{8} & \multirow[t]{2}{*}{8} \\
\hline Воротники & 4 & 4 & 4 & 4 & & & & \\
\hline Сторожа & 2 & 2 & 2 & 2 & 2 & 2 & 2 & 2 \\
\hline Кузнецы & 1 & 1 & 1 & 1 & 1 & 1 & 1 & 1 \\
\hline ИТОГО * & 374 & 374 & 324 & 324 & 324 & 323 & 323 & 324 \\
\hline $\begin{array}{l}\text { Годоваль- } \\
\text { щики } \\
\text { Сотники } \\
\text { стрелецкие }\end{array}$ & 1 & 1 & 1 & 1 & - & - & 1 & - \\
\hline $\begin{array}{l}\text { Стрельцы } \\
\text { конные }\end{array}$ & - & - & - & - & - & - & & - \\
\hline $\begin{array}{l}\text { Стрельцы } \\
\text { пешие }\end{array}$ & $\begin{array}{c}50 \\
\text { (Свияжск) }\end{array}$ & $\begin{array}{c}50 \\
\text { (Свияжск) }\end{array}$ & $\begin{array}{c}50 \\
\text { (Свияжск) }\end{array}$ & $\begin{array}{c}50 \\
\text { (Ядрин, } \\
\text { Царево- } \\
\text { санчюрск, } \\
\text { Яранск) } \\
\end{array}$ & $\begin{array}{c}50 \\
\text { (Кузьмодемь- } \\
\text { янск, Царево- } \\
\text { кокшайск, } \\
\text { Уржум) } \\
\end{array}$ & $\begin{array}{c}50 \\
\text { (Кузьмодемь- } \\
\text { янск, Царево- } \\
\text { кокшайск, } \\
\text { Уржум) } \\
\end{array}$ & $100 * *$ & $\begin{array}{c}50 \\
\text { (Кузьмо- } \\
\text { демьянск, } \\
\text { Ядрин) }\end{array}$ \\
\hline ВСЕГО * & 425 & 425 & 375 & 375 & 374 & 373 & 424 & 374 \\
\hline
\end{tabular}

Примечание. *- не считая воевод; ** - 50 свияжских во главе с сотником и 50 «понизовых» городов: Свияжск (так в РК), Чебоксары, Цывильск, Кузьмодемьянск, Царевококшайск, Уржум.

\begin{tabular}{|c|c|c|c|c|c|}
\hline Люди & 7141 г. & 7143 г. & 7144 г. & 7146 г. & «Смета 1651 г.» \\
\hline Воевода & кн. Л.М. Волконский & И.Б. Свищов & T.В. Шушерин & Т.В. Шушерин & И.Ф. Акинфов \\
\hline Подьячие & - & - & - & - & 2 \\
\hline Дети боярские & 5 & 5 & 5 & 3 & 5 \\
\hline $\begin{array}{l}\text { Голова } \\
\text { стрелецкий }\end{array}$ & 1 & 1 & 1 & - & 1 \\
\hline $\begin{array}{l}\text { Сотники } \\
\text { стрелецкие }\end{array}$ & 3 & 3 & 3 & 3 & 3 \\
\hline Стрельцы конные & 100 & 100 & 100 & 100 & 100 \\
\hline Стрельцы пешие & 200 & 200 & 200 & 200 & 400 \\
\hline Вожи & 3 & 3 & 3 & 3 & 3 \\
\hline Толмачи & 1 & 1 & 1 & 1 & 1 \\
\hline Пушкари & \multirow[t]{2}{*}{8} & \multirow{5}{*}{14} & \multirow[t]{2}{*}{8} & \multirow[t]{2}{*}{8} & 4 \\
\hline Воротники & & & & & 4 \\
\hline Сторожа & 2 & & 2 & 2 & 2 \\
\hline Кузнецы & 1 & & 1 & 1 & 1 \\
\hline «Деловые люди» & - & & 2 пивовара & - & - \\
\hline ИТОГО * & 324 & 327 & 326 & 321 & 518 \\
\hline $\begin{array}{l}\text { Годовальщики } \\
\text { Сотники } \\
\text { стрелецкие } \\
\end{array}$ & - & - & - & - & - \\
\hline Стрельцы конные & - & - & - & - & - \\
\hline Стрельцы пешие & $\begin{array}{c}50 \\
\text { (Кузьмодемьянск, } \\
\text { Царевококшайск, } \\
\text { Уржум) } \\
\end{array}$ & $\begin{array}{c}50 \\
\text { (понизовые } \\
\text { города) }\end{array}$ & $\begin{array}{c}50 \\
\text { (понизовые } \\
\text { города) }\end{array}$ & $\begin{array}{c}50 \\
\text { (понизовые } \\
\text { города) }\end{array}$ & - \\
\hline ВСЕГО * & 374 & 377 & 376 & 371 & 518 \\
\hline
\end{tabular}


В 133-м (1624/25) и в 134-м (1625/26) гг. при воеводе Д.П. Новосильцеве в Царицыне служили: 5 детей боярских, 3 вожа, 1 толмач, 4 воротника, 4 пушкаря, 2 сторожа, 1 кузнец, 1 голова, 3 сотника и 350 конных и пеших стрельцов; на годовой - из Свияжска сотник с 50 стрельцами пешими [15, стб. 1033-1034, 1142-1143, 1249-1250]. Итого в разрядные записи по Царицыну внесено 425 служилых людей: 374 царицынских и 51 годовальщик. В 1626 г. Новосильцев «за вину с Царицына послан в Астарахань», а город и воеводство у него принял Семен Федоров сын Глебов, при котором в 135 -м (1626/27) г. состав и численность служилых людей в Царицыне оставались без изменений $[15, \text { стб. } 1249,1355]^{6}$. В 136-м (1627/28) г. Глебова сменил Матвей Игнатьев сын Зубов, при котором приказ царицынских стрельцов уменьшился на 50 чел., а конная стрелецкая сотня в росписи была отделена от двух пеших, да 50 пеших стрельцов на годовую прислали из Уржума, а в 137-м $(1628 / 29)$ г. - из Ядрина, Царевосанчюрска и Яранска; в остальном состав царицынских служилых людей оставался неизменным в течение двух лет воеводства Зубова [16, стб. 87, 191].

Разряд 138-го (1629/30) г. при воеводстве кн. Льва Михайлова сына Волконского меняет эту картину лишь исчезновением головы стрелецкого (смерть?) и переменой годовальщиков из Кузьмодемьянска, Царевококшайска и Уржума [16, стб. 287] ${ }^{7}$. В 139-м (1630/ 31) г. при том же князе Волконском годовальщиков переменили те же города, а стрелецкий голова так и не появился, зато в 2 раза было увеличено число годовальщиков: к 50 свияжским стрельцам во главе с сотником присланы были 50 сборных стрельцов из разных «понизовых» городов [16, стб. 353] ${ }^{8}$. В «Смете 139-го (1630/31) г.» в Царицыне записан стрелецкий голова Василий Стромилов, а царицынским воеводой - Матвей Игнатьев сын Зубов, однако сведения о годовальщиках соответствуют наряду 138-го (1629/30) г. «Смета 139-го г.» на Царицыне в деталях повторила данные разрядов, но не за 139-й, а частью за 137-й, частью - за 138-й гг. (sic!) [32, c. 45]. Таким образом, можно предполагать, что в «Смету 139-го г.» по Царицыну были внесены данные годовой, а то и двух- летней давности - компилят из росписей за 2 года. Вероятно, на момент составления в 139-м г. в Разряде сметы данных за текущий год в распоряжении подьячих еще не было.

В Разряде 140-го (1631/32) г. вдруг снова перечислены лишь воеводы, включая царицынского кн. Никифора Федорова сына Мещерского [16, с. 687]. И вновь картина со «Сметой 1632 г.» аналогична предыдущей «Смете»: в 1632 г. воеводой в Царицыне записан все еще князь Волконский, которого в действительности к тому моменту уже сменил князь Мещерский, из чего следует, что «Смета 1632 г.» отразила данные 139-го или даже 138-го годов. По «Смете 1632 г.» в Царицыне было 374 служилых человека: 5 детей боярских, 1 голова и 3 сотника стрелецких, 100 стрельцов конных и 200 пеших, 3 вожа, 1 толмач, 8 пушкарей и воротников, 2 сторожа и 1 кузнец, которые усиливались годовальщиками - 50 кузьмодемьянскими и ядринскими стрельцами. К данным 138-го г. скорее всего апеллируют и сведения о годовальщиках, потому что в 139-м их число было увеличено до 100 стрельцов с сотником во главе. Из 350 стрельцов, служивших в Царицыне, по данным «Сметы 1632 г.» стрельцов 20 конных и 80 пеших во главе с сотником воевода в качестве отработки государственной повинности должен был посылать на «кирпичную и каменную ломку» - разбор золотоордынских городищ на р. Ахтубе и отправке кирпича и камня «к астараханскому городовому делу» [34, c. 75].

Князь Лев Волконский вернулся на воеводство в Царицын в 141-м (1632/33) г., когда вновь разрядная книга сообщила роспись царицынского гарнизона, в котором у царицынских стрельцов появился голова, а численность годовальщиков вновь вернулась к сборной команде в 50 пеших стрельцов из Кузьмодемьянска, Кокшайска и Уржума $[16, \text { с. } 742]^{9}$. Записи за 142-й (1633/34) г. в разрядных книгах отсутствуют, если не считать Разряда Смоленской войны, но состав гарнизонов и администрации городов она не отразила.

В Разряде 143-го (1634/35) г. воеводой написан Иван Борисов сын Свищов, а служилых людей ни число, ни состав не изменились, за исключением того, что в единый блок в 14 человек оказались сведены воротники, пуш- 
кари, сторожи, кузнецы и «деловые люди», а 50 годовальщиков написаны из «понизовых городов» (в том числе 30 кузьмодемьянских) $[16$, стб. 819, 824]. Сопоставление с росписями предыдущих и последующих годов позволяет утверждать, что впервые появившихся «деловых людей» было 3 человека.

В 144-м (1635/36) г. Свищов был отозван в Москву, а на его место прислан Тимофей Васильев сын Шушерин, который принял у своего предшественника гарнизон в том же составе, кроме того, что число «деловых людей» уменьшилось до двух, и роспись уточнила род их деятельности - это оказались пивовары (вероятно, первое упоминание о варке пива в Царицыне) [16, стб. 922]. За 145-й (1636/37) г. данные не известны, зато в 146-м (1637/38) г. с тем же воеводой Шушериным из росписи гарнизона вновь исчез стрелецкий голова и «деловые люди», а число детей боярских уменьшилось до трех [27, с. 117].

Если до разорения Смуты (1608-1615) администрация Царицына была представлена воеводами из сравнительно знатных лиц, а делопроизводством вроде бы руководил дьяк $[29$, с. $338-341 ; 28$, с. 384-388; 30, с. 5-11], то после восстановления крепости до 1651 г. среди служилых людей не упоминаются даже подьячие, а многие воеводы явно не принадлежат к числу московской княжеско-боярской аристократии. По 146-й (1637/38) г. на Царицыне не упоминаются не только дьяки, но и казенные подьячие, которых пока впервые фиксирует в Царицыне лишь «Смета 1651 г.». В такой ситуации городское делопроизводство воеводской (и/или съезжей) избы обычно велось наемными площадными подьячими.

По «Смете 1651 г.» в Царицыне с воеводой служили 518 человек. Заметные изменения произошли в численности стрельцов, пушкарей и воротников. Численность пеших стрельцов выросла в 2 раза, зато в Царицын перестали присылать годовальщиков. И хотя общее число конных и пеших стрельцов выросло до 500 чел., возглавлялись они по-прежнему лишь тремя сотниками, а голова стрелецкий в Царицыне вновь отсутствовал. Численность прочих служилых осталась на прежнем уровне ${ }^{10}$.

Из 72 человек, пожалованных на Казенном дворе в 1616-1622 гг. за различные цари- цынские службы, служилые люди жаловались за выход (царицынский, астраханский, станичный) ${ }^{11}$, за службу (нагайскую, волжскую), за сеунч, за приезд (царицынский) ${ }^{12}$, за головство ${ }^{13}$, за полонское терпение, за рану, «для крещения», «за царицынское строение» («за царицынское городовое поставленье») и «за царицынское острожное дело». Особняком стоит единственное пожалование за крещение, что при кажущейся ясности на самом деле предполагает целый ряд интерпретаций с учетом характерных именно для данного исторического момента политических обстоятельств [5].

В записях расходных книг Казенного двора за 1616-1622 гг. упомянут лишь один царицынский воевода - это строитель Царицынской крепости свияженин, потом нижегородец Мисюрь Соловцов, ему посвящены два развернутых биографических очерка [12, c. $142-151 ; 13$, с. 35-50], почему на этой фигуре деятеля Смутного времени мы останавливаться не будем. Сама запись о награждении его за строительство Царицынской крепости была опубликована в выписках Забелина и рано вошла в научный оборот, хотя и с ошибочной датировкой 23 марта ${ }^{14}$.

В своих дополнениях к Дворцовым разрядам Забелин также пересказал запись о пожаловании царицынских стрельцов за их труды по строительству Царицынской крепости, однако пропустил участвовавшего в строительстве Тимофея Иванова сына Стрешнева, на момент пожалования его в 1619 г. имевшего чин стряпчего. В августе 1619 г. Тимофей с братом Иваном били челом об освобождении одного из них от участия в царском богомолье «для их бедности и разоренья», государь пожаловал их 12 августа: «быть в походе одному» [1, с. 154]. По характеру пожалования не только сукном, но и шелком Т.И. Стрешнев на Царицынском строительстве был головой, но вопрос о времени его службы по строительству остается пока открытым: строил ли он ее вместе с Coловцовым и занимался ее достройкой и после него до 1619 г., или это была позднейшая достройка крепости, не связанная с первыми восстановительными работами воеводы Соловцова. 1 августа 1626 г. Тимофея с братом Иваном Ивановых детей и с Автомоном Алек- 


\section{ИСТОРИЯ СМУТНОГО ВРЕМЕНИ}

сеевым сыном Стрешневых царь пожаловал из стряпчих в стольники [26, с. 28,35$]$ при богомолье своем в Симоновом монастыре [11, c. 402]. Вместе с братом Иваном они написаны в стольниках в боярских списках 1627/28, $1628,1629,1629 / 30$ гг. [26, с. $107,185,263,335]$. Сохранилось немало упоминаний о землевладении и брачной деятельности Тимофея Стрешнева по поиску богатых невест, которые могут составить отдельную биографическую статью этого московского чина.

Сегодня остается открытым вопрос об источниках формирования гарнизона Царицына от начала его восстановления в 1615 г. и до 1624 г., пролить свет на который позволяет информация из расходных книг Казенного двора. Как мы видели выше, в 1620-х - начале 1650-х гг. на втором месте после воеводы по своему статусу и положению был стрелецкий голова. За рассматриваемый нами период упоминаются 2 головы стрелецких: Степан Васильев сын Мертвый (из муромских детей боярских, потом переписан службой по Алатырю) - в январе 1617 г. и Андреян Ларионов сын Черевин (из галицких детей боярских) в декабре 1620 года ${ }^{15}$.

Следующее место в социально-служилой иерархии Царицына занимали дети боярские, которые в первой половине столетия были представлены всего 5 людьми за отсутствием в Царицыне в эти годы поместно-вотчинного землевладения. Книги Казенного двора сохранили имена троих из них: Ивана Быкова, Василия Хромого и Федора Ярышкина. О первом известны лишь два его пожалования как головы проезжей станицы в составе вожа и стрельцов: 17 апреля 1618 г. и 23 декабря 1621 г. (см. приложение). Царицынский сын боярский Василий Хромой (Хромого, Хромов) также дважды получал жалованое на Казенном дворе в том же качестве и составе, что и И. Быков: 15 января 1620 г. и 25 марта 1622 г. (см. приложение). Судя по пожалованиям, возглавлять сотни и станицы, посылаемые царицынскими воеводами по указам из Москвы и по вестям и доставку в столицу в Приказ Казанского дворца вестей и людей было главной задачей царицынских детей боярских, и пятеро их вполне справлялись с этой задачей. Основ же для формирования полноценного уезда и уездной поместной корпорации не было до появления хоть как-то защищенных земель от военно-криминальной угрозы как со стороны кочевников, так и донских, яицких и волжских казаков. Поэтому основной опорой власти как центральной, так и воеводской в городе и на контролируемой Царицынской крепостью территории, по крайней мере до возведения в 1650-е гг. Закамской черты, а фактически до конца столетия, оставались стрельцы. Упоминание третьего - Ф. Ярышкина - в пожаловании 29 сентября 1619 г. 5-ти царицынских детей боярских с ним во главе за язычный привод (см. приложение) указывает на сформирование той пятерки, которую будут составлять царицынские дети боярские всю первую половину столетия.

Прочие, не называвшиеся царицынскими, но приезжавшие с Царицына в Москву во главе проезжих станиц служилые люди скорее всего находились в Царицыне временно и представлялись по месту своего испомещения и записи в десятни.

Исключением является сотник казанских стрельцов Федор Борисов из муромских детей боярских, явно «годовавший» со своими стрельцами в Царицыне в январе 1619 года. В Царицыне он оказался после участия еще как муромский сын боярский в обороне Москвы от войск королевича Владислава в 1618 г., за что был пожалован вотчиной из своего поместья в Дубровском стане Муромского у., которую наследовали его сыновья жильцы Семен и Дмитрий [25, с. 397].

В числе детей боярских, приезжавших в «проезжих службах» из Царицына, встречаем одного казанского жильца, двух курмышан и двух алатырцев. Первым из них в Москву приехал курмышанин Богдан (Захарьев сын) Моклоков (Маклаков) - 28 февраля 1616 г., когда был пожалован за царицынский выход и за сеунч. Однако в книгу сеунчей он вписан не был $[14$, с. $40-41]$, из чего можно заключить, что сеунч он привез не о «кровных» службах и не дипломатических - скорее всего, с вестью, что крепость возведена. Ранее его имя встречается в книгах Печатного приказа, где 29 июня 1613 г. по его челобитью запечатали 2 грамоты в Курмыш о сыске про поместье Василия Ртищева и о сыске про пустошь [9, с. 203, 205]. В дальнейшем Богдан Захарьев сын Моклоков в московском осад- 
ном списке 1618 г. написан «по Курмышу» в списке городовых дворян и детей боярских, которые были по полкам с воеводами [25, c. 73]. За московское осадное сидение 1618 г. он получил жалованную вотчину в Завацком стане Курмышского у. [25, с. 160, 300, 452]. В августе 1657 г. некий Богдан Моклоков упомянут как землевладелец в Белозерском у. [24, c. 166].

Казанским жильцом, возглавившим проезжую царицынскую станицу в июле 1616 г., был написан Иван (Семенов сын) Языков, которого можно осторожно соотнести с арзамасцем Иваном Языковым, представившим 15 июня 1613 г. в Печатном приказе 2 грамоты: о сыске беглых и отказную «по прежней даче» $[9$, с. 163]. Жилец Иван Семенов сын Языков был в полках при обороне Москвы «в королевичев приход», согласно московскому осадному списку 1618 г. [25, с. 49]. За свои службы он получил 3 жалованные вотчины в Пошехонском у. (2 - в Белосельской волости и 1 - в Шигорашской) [25, с. 200, 382]. 9 мая 1630 г. Иван Семенов сын Языков пожалован в дворяне московские и внесен в боярские списки 1629/30, 1630/31, 1631/32, 1632/33 гг. [26, c. $391,439,499,521]$.

В июле 1616 г. И.С. Языков приезжал в Москву из Царицына вместе с курмышанином Степаном Евлашевым, но о жизни и службе последнего сведений пока найти не удалось.

В начале июля 1617 г. с «царицынской службой» в Москву во главе станицы «вышел» алатырец Федор (Ратманов, Рахманов, Рахманинов, Романов сын) Бурцев. Его имя впервые нам удалось найти в записи книг Печатного приказа о запечатанной грамоте на Рязань по челобитью Ивана Филитова на Федора Бурцева «о управе в бою и в грабеже» [9, c. 145]. Позже он участвовал в боях за Москву: Федор Ратманов (Романов, или Рахманов?) сын Бурцев в московском осадном списке 1618 г. написан в выборе «по Свияжску» в списке городовых дворян и детей боярских, которые были по полкам с воеводами, испомещен в Нижегородском у. [25, с. 73, 223]. За московское осадное сидение Ф.Р. Бурцев пожалован вотчиной в Березопольском стане Нижегородского у., которая перешла по наследству к матери Анне и брату Степану [25, c. 523]. В выписи Казанского дворца 1689 г. из писцовых книг 1623-1626 гг. и переписных книг 1645/46 г. Федор Рахманинов сын Бурцев с сыном жильцом Данилой перечислены как бывшие владельцы вотчин Троицкого Макарьева Желтоводского унженского монастыря в Алатырском у. [24, с. 29].

Алатырец Иван Пасмуров (Пасморов), приезжавший из Царицына в Москву в январе 1618 г., вероятно, приходился родственником царицынскому сотнику стрелецкому Федору Пасмурову. В выписи Казанского дворца 1686 г. из писцовых книг 1623-1626 гг. с пометами 1634-1686 гг. Иван Ратаев сын и его племянник Иван Дмитриев сын Пасмуровы перечислены как бывшие владельцы вотчин Троицкого Макарьева Желтоводского унженского монастыря в Алатырском у. [24, с. 26].

И казанский жилец, и курмышане, и арзамасцы несли службу на Царицыне до тех пор, пока там не сформировалась устойчивая пятерка царицынских детей боярских, а именно, не позднее конца сентября 1619 г., когда пятерка царицынских детей боярских была полностью укомплектована. Это завершение формирования «зародыша» царицынской служилой корпорации представляется правильным связать с окончанием московского похода королевича Владислава и подписанием Деулинского перемирия.

Нам пока не известно, появился ли голова стрелецкий в Царицыне вместе с воеводой, или это произошло позже, поскольку в конце Смуты и первые послесмутные годы реальными командирами стрельцов зачастую оказывались стрелецкие сотники, а не головы [20, с. 615-623]. Сотников царицынских стрельцов с 1616 по 1622 г. на Казенном двоpe жаловали четырех человек: Четвертого Дмитриева (февраль 1617 г.); Константина Ступина (из курмышан - январь и декабрь 1618 г., декабрь 1620 г., январь 1621 г.); Данилу (Григорьева сына?) Вотманова (из алатырцев? - в июле 1620 и сентябре 1627 г.); Федора Пасмурова (из алатырцев? - в июле 1622 г.).

Из сохранившихся имен 25-30 царицынских стрельцов лишь у 5 человек встречаются прозвища по месту происхождения (Курмышенин, Епифанец, Кинешемец, Мещеряк, Хоперский). Абсолютное большинство цари- 


\section{ИСТОРИЯ СМУТНОГО ВРЕМЕНИ}

цынских стрельцов не имели фамилий, это говорит в пользу того, что родом они были из Царицына. Прозвища, в первую очередь по месту происхождения, не имеющим фамилий служилым по-прибору давались для их идентификации тем чаще, чем многочисленнее был стрелецкий гарнизон. Следует оговориться, что прозвищ обычно не имели урядничьи чины: стрелецкие пятидесятники и десятники, для которых сам чин являлся идентифицирующим признаком.

Неустойчивая численность награжденных на Казенном дворе стрельцов связана с тем, что из 8 царицынских вожей, которые упоминаются в книгах Казенного двора, по крайней мере часть имела за плечами стрелецкую службу. Учитывая, что более 3 казенных вожей за 1-ю половину столетия в Царицыне не упоминаются, а умирали они не чаще прочих служилых, можно уверенно предположить, что некоторые из них так и числились стрельцами, а при получении жалованья на Казенном дворе их записывали по факту исполняемой ими службы.

Яркий пример «вожеских служб» продемонстрировал царицынский стрелец, а потом вож Архипка Гаврилов из казанских стрельцов. 13 сентября 1614 г. еще в качестве казанского стрельца он в составе своей станицы казанского жильца Куприяна Дубровина вместе со своим товарищем и со служилыми новокрещеным и татарином получил на Казенном дворе 6 арш. сукна еренка темно-синего (1 руб. 8 алт. 2 ден.) «за донскую службу и за изрон» ${ }^{16} .18$ июля 1616 г. и 8 июля 1617 г. он как царицынский вож получил на Казенном дворе жалованье за службы и приезд к Москве (см. приложение). 19 июля 1620 г. он также как вож получил жалованье «для крещенья» (при этом имя его не изменилось), что позволяет предположить, что получил он это жалованье задним числом с большим опозданием, так как при пожаловании прежнее и новое крестильное имя писалось практически всегда. Его этническое происхождение идет, можно полагать, как из поволжских народов, так и из народов Речи Посполитой, представители ко- торых (литвины, черкасы, поляки еtс) традиционно отправлялись в ссылку на житье и службу в Казань. Последнее могло бы объяснить перекрещивание православного литвина или черкаса, волна каковых прошла по стране после возвращения из плена Филарета Никитича и избрания его на патриаршество в 1619 году. Однако после пожалования за крещение, выполняя вожескую службу и даже возглавляя проезжую станицу, записывается в книги то вожем, то стрельцом: 21 июля 1620 г. - как стрелец, 2 июля 1621 г. - как вож, 21 июня 1622 г. - во главе проезжей станицы из 3 царицынских стрельцов (см. приложение).

Результаты. На протяжении первых лет существования восстановленного Царицына на Казенном дворе жаловали за царицынский выход, сеунчь и службы, и вполне можем предполагать, что суть этих служб сводилась к восстановительным работам в крепостях Нижнего Поволжья и организации связи их с Москвой. Так, на царицынских вожах лежала обязанность провожать до Москвы и обратно астраханские проезжие станицы. Помимо «царицынского строения» и «проезда» - «выхода» службы редко уточняются. 26 января 1620 г. конный стрелец Лифантий Неверов получил жалование за плен, но где он был в плену - осталось неизвестным. Уже в сентябре 1619 г. царицынские дети боярские жаловались за взятых языков, но лишь с 1620 г. мы встречаем пожалования «за волжскую службу» (7 июня 1620 г., 15 января 1621 г.), «за нагайскую службу» (3 января 1621 г.), за посылки с Царицына «на воровских казаков и азовских людей» (16 августа 1622 г.). Эти записи с сентября 1619 г. дают основание предположить, что гарнизон Царицына следом за крепостью был вполне восстановлен и способен не только оборонять крепость, но и всю подконтрольную этой крепости территорию, осуществляя основные функции по борьбе с казачьими разбоями на Волге и очищая от азовских, нагайских и казачьих грабителей подходившие к Царицыну с запада и востока участки степных дорог [6, c. 202-203, 208-211, 214]. 
ПРИЛОЖЕНИЕ

\section{ХРОНИКА \\ пожалований на Казенном дворе \\ царицынских и иных служилых людей за царицынские служб̆ы}

7124-й г.

1616 г.

Февраль

25

Царицынские стрельцы Василий Агафонов, Дружина Иванов, Фома Степанов, Богдан Кузмин, Обросим Клементьев, Афанасий Алексеев, вож Иван Филиппов - по портищу сукна настрафиля темно-синего - «за царицынской выход и за службу и за сеунчь» ${ }^{17}$.

28

Курмышенин Богдан Моклоков - дараги червчатые, портище сукна настрафиля лазоревого - «за царицынской выход и за сеунчь» ${ }^{18}$.

\section{Март}

2

Царицынские стрельцы Василий Агафонов, Дружина Иванов, Фома Степанов, Богдан Кузмин, Обросим Клементьев, Иван Сеченой - по 1 руб. за «суконца» - «за Царицынское острожное дело, что они острог и церкви поставили, и за приезд» ${ }^{19}$.

\section{Июль}

18

Казанский жилец Иван Языков - портище сукна настрафиля лазоревого; курмышенин Степан Евлашев портище тафты немецкой лазоревой; царицынские вож Архип Гаврилов, стрелец Калина Елизарьев - «по портищу сукна настрафиля лазоревого» «за царицынскую службу и за выход» ${ }^{20}$.

7125-й г.

Декабрь

26

Царицынские стрельцы Андрей Иевлев, Кирилл Федоров - по портищу сукна настрафиля лазоревого «за выход» 21.

1617 г.

Январь

3

Царицынский голова стрелецкий Степан Мертвый - портище сукна английского багрового, дараги червчатые - «за службу и за царицынской приезд» 22.

\section{Февраль}

13

Царицынский сотник стрелецкий Четвертой Дмитриев - портище сукна настрафиля лазоревого; царицынский стрелец Остафий Хоперский - портище сукна лятчины лазоревой - «за царицынской выход» ${ }^{23}$.

\section{Июль}

Алатырец Федор Бурцов - портище сукна настрафиля лазоревого, дараги зеленые; царицынский вож Архип Гаврилов, царицынские стрельцы пятидесятник Потап Васильев, рядовые Семен Титов, Остафий Семенов, 


\section{ИСТОРИЯ СМУТНОГО ВРЕМЕНИ}

Мина Федоров, Максим Григорьев, Данила Кузмин, Смола Ефимов, Семен Копыто, Ерофей Степанов, Ждан Петров - по портищу сукна настрафиля лазоревого - «за царицынскую службу и за выход» ${ }^{24}$.

7126-й г.

1618 г.

Январь

3

Царицынские сотник стрелецкий Константин Ступин, конные стрельцы пятидесятник Потап Васильев, рядовые Андрей Иевлев, Иван Нагиба, Владимир Иванов - по портищу сукна настрафиля лазоревого - «за службу и за выход» ${ }^{25}$.

31

Алатырец Иван Пасморов (Пасмуров) - портище сукна настрафиля лазоревого - «за Царицынскую службу и за выход» ${ }^{26}$.

\section{Апрель}

17

Царицынские станичники царицынский жилец Иван Быков, царицынский стрелецкий пятидесятник Первой Иванов - по портищу сукна настрафиля лазоревого - «за службу и за выход» ${ }^{27}$.

\section{7-й г.}

\section{Сентябрь}

29

Царицынские дети боярские Федор Ярышкин с четырьмя товарищами - по портищу сукна английского багрового - «за язычной привод» ${ }^{28}$.

\section{Декабрь}

30

Царицынские сотник стрелецкий Константин Ступин, стрельцы Василий Угримов, Степан Алекин - по портищу сукна настрафиля лазоревого - «за службу и за царицынский выход» 29.

\section{9 г.}

\section{Январь}

15

Царицынский станичник казанский сотник стрелецкий Федор Борисов - портище сукна настрафиля лазоревого - «за службу и за выход» ${ }^{30}$.

7128-й г.

\section{Сентябрь}

22

Астраханские станичники сын боярский Данила Кастеев, сотник стрелецкий Иван Тырков - по портищу сукна настрафиля лазоревого, по портищу тафты виницейки; астраханские стрельцы Иван Евдокимов, Семен Захарьев, Петр Васильев, Иван Григорьев, Михаил Филиппов, царицынский вож Иван (?) - по портищу сукна настрафиля лазоревого - «за астароханской выход» ${ }^{31}$.

\section{Ноябрь}

\section{6}

Астраханские станичники сын боярский Андрей Тарбеев, сотник стрелецкий Андрей Топорков - по портищу тафты виницейки и по портищу сукна настрафиля лазоревого; астраханские стрельцы пятидесятник Иван 
Соколов, десятник Алексей Новгородец, рядовые Кирилл Перфирьев, Ларион Марков, «Филька» (Филипп или Филимон?) Семенов, Михаил Иванов, Малах Патрекеев, Докучай Дмитриев, Агей Орленин и царицынский вож Ждан Карпов - по портищу сукна настрафиля лазоревого - «за службу и за астороханской выход» ${ }^{32}$.

1620 г.

\section{Январь}

15

Царицынские станичники сын боярский Василий Хромой, вож Андрей Холуй, стрельцы Олифантий Самсонов, Иван Фатьянов - по портищу сукна настрафиля червчатого - «за службу и за станичной выход» ${ }^{33}$.

20

Тимофей Иванов сын Стрешнев - портище сукна кострыша темно-синего и портище камки адамашки жолтой - «за Царицынское строение» ${ }^{34}$.

26

Царицынский конный стрелец Лифантий Неверов - портище сукна лятчины лазоревой - «за полонское терпенье» $^{35}$.

\section{Март}

24

Воевода Мисюрь Соловцов - портище камки адамашки лазоревой и портище сукна английского темносинего - «за царицынское городовое поставленья» ${ }^{36}$.

\section{Июнь}

Астраханские и терские станичники дети боярские Марк Дрозжин и Роман Протасов - по портищу тафты виницейки лимонной и по портищу сукна настрафиля лазоревого; да астраханские стрельцы Григорий Игнатьев, Иван Иванов, Обакум Филиппов, Савва Юрьев, Богдан Федоров, Семен Иванов, Федор Иванов, Василий Иванов, Семен Вологженин, терский стрелец Иван Иванов, Воин Федоров, царицынский вож Иван Филиппов - по портищу сукна настрафиля лазоревого - «за астраханской выход» ${ }^{37}$.

7

Царицынский вож Иван Филиппов - портище сукна лятчины лазоревой - «за Волскую службу и за рану» ${ }^{38}$.

\section{Июль}

14

Царицынский сотник стрелецкий Данила Ватманов - портище сукна настрафиля лазоревого - «за Царицынскую службу» ${ }^{39}$.

19

Царицынский вож Архип Гаврилов - портище сукна настрафиля лазоревого - «для крещенья» ${ }^{40}$.

\section{1}

Царицынский сотник стрелецкий Данила Ватманов и стрельцы Архип Гаврилов, Иван Белоус, Василий Угримов, Степан Алекин (Олекин), Кузьма Чекунов, Василий Банщиков - по портищу сукна еренка лазоревого «за царицынской выход» ${ }^{41}$.

\section{9-й г.}

\section{Декабрь}

Царицына города голова стрелецкий Андреян Черевин (Черево) и сотник стрелецкий Константин Стулин по портищу сукна настрафиля лазоревого; вож Андрей Холуй, стрельцы Михаил Федотов, Максим Макарьев, Исаак Ильин, Федор Федоров - по портищу сукна лятчины лазоревой - «за царицынской выход» ${ }^{42}$. 
1621 г.

Январь

3

Царицынский голова стрелецкий Андреян Черевин - портище сукна настрафиля лазоревого - «за нагайскую службу» ${ }^{43}$.

15

Астраханские сотник стрелецкий Дмитрий Горожанкин и подьячий Терентий Матвеев - по портищу сукна настрафиля лазоревого; стрельцы Семен Яковлев, Ян Алексеев, Василий Молафеев, Меньшик Федоров, царицынский вож Ждан Карпов - по портищу сукна лятчины лазоревой - «за астароханской выход» ${ }^{44}$.

Царицынский сотник стрелецкий Константин Ступин - портище сукна настрафиля лазоревого - «за службу, что он был посылан на Волгу за воровскими казаки» ${ }^{45}$.

Март

19

Царицынский пятидесятник стрелецкий Замятня Полуектов - портище сукна лятчины лазоревой - «за выход» ${ }^{46}$.

Июль

2

Царицынский вож Архип Гаврилов, стрельцы Степан Лехин, Данила Кузмин - по портищу сукна кострыша темно-синего - «за Царицынской выход» ${ }^{47}$.

\section{0-й г. \\ Декабрь}

13

Царицынские пятидесятники стрелецкие Лифантий Самсонов и Иван Федоров, конный стрелец Степан Мещеряк; вож Иван Сеченый - по портищу сукна настрафиля лазоревого - «за царицынской выход» ${ }^{48}$.

23

Царицынские станичники сын боярский Иван Быков, вож Ждан Ложник, стрельцы Замятня Полуектов, Семен Кинешемец, Данила Кузмин, Лазарь Вороженин - по портищу сукна настрафиля лазоревого - «за службу и за выход» ${ }^{49}$.

1622 г.

Март

25

Царицынские станичники сын боярский Василий Хромой, стрелец Кузьма Васильев сын Курмышенин - по портищу сукна настрафиля лазоревого - «за царицынской выход» ${ }^{50}$.

\section{Июнь}

21

Царицынские вож Архип Гаврилов и стрельцы Данила Кузмин, Василий Угримов, Федор Угловатый - по портищу сукна настрафиля лазоревого - «за царицынской приезд» ${ }^{51}$.

\section{Июль}

30

Царицынские станичники сотник стрелецкий Федор Пасмуров, вож Иван Филиппов, стрельцы Давыд Епифанец, Алексей Сахаров - по портищу сукна настрафиля лазоревого - «за царицынской приезд» ${ }^{52}$.

\section{Август}

16

Андреян Черевин - портище сукна английского мурамно-зеленого - «за царицынскую службу 128-го и 129-го году и за головство, что он в тех годех посылан был с Царицына на воровских казаков и на азовских людей» ${ }^{53}$. 


\section{ПРИМЕЧАНИЯ}

${ }^{1} \mathrm{O}$ самих книгах как источнике мы неоднократно уже писали, что позволяет сократить этот очерк, отослав к вышедшим ранее публикациям $[22 ; 23]$.

2 Только Андрушевич перепутал Салтыковых: воеводу Ивана Никитича с дипломатом Михаилом Глебовичем, бежавшим в конце Смуты в Речь Посполитую. Версия Барсукова, что войско отправил из Москвы уже взошедший на трон Василий Шуйский, не подтверждается источниками, как и попытка представить отход к Царицыну как наступление на Астрахань [3, с. 108, 122-128].

${ }^{3}$ Барсуков в своем справочнике в отношении его оперировал данными исключительно опубликованных разрядных книг.

${ }^{4} \mathrm{O}$ жалуемых тканях и размерах жалованных портищ см.: [17, с. 34-52].

${ }^{5}$ Список и биографические справки по названным царицынским воеводам см.: [6, с. 11-13; 36, с. 183-195].

${ }^{6}$ В Разряде 135 г. не внесены пушкари, но, судя по неизменившейся итоговой цифре, имеет место обычная прописка подьячего.

${ }^{7}$ В РК 1550-1636 гг. указано только назначение князя Волконского и его перемена в 140-м (1631/ $32)$ г., причем имя сменившего так и осталось невписанным.

${ }^{8}$ Годовальщиков из Кузьмодемьянска - 20, из Царева-Кокшайска - 15 стрельцов [16, стб. 358, 359].

${ }^{9}$ Годовальщиков из Кузьмодемьянска - 20, из Царева-Кокшайска - 15 стрельцов [16, стб. 747, 748].

${ }^{10}$ В Смете ошибочно написано 508 чел. [31, c. 25].

${ }^{11}$ О понятии «выход» в делопроизводственной практике конца Смуты см.: [18, с. 157-195].

${ }^{12}$ О смысловых параллелях понятий «выезд» и «приезд» в делопроизводстве Казенного двора см.: [21, с. 157-184].

${ }^{13}$ О чинах командиров среднего звена см.: [19, c. 78-79].

14 РГАДА. Ф. 396. Архив Оружейной палаты. Оп. 2. Кн. 205. Л. 278 об.-279. У Забелина ошибочно записано 23 марта [10, стб. 205-206].

15 Более подробные биографические данные будут приведены в отдельной статье по головам и сотникам стрелецким.

16 РГАДА. Ф. 396. Архив Оружейной палаты. Оп. 2. Кн. 277. Л. 15-16.

17 Там же. Кн. 278. Л. 139 об.-140.

18 Там же. Кн. 278. Л. 144 об.-145.

${ }^{19}$ Там же. Кн. 68. Л. 179-179 об. Запись частично опубликована: [6, с. 51-52].

20 Там же. Кн. 278. Л. 234 об.-235.

21 Там же. Кн. 279. Л. 108-108 об.
22 Там же. Л. 121 об.-122.

${ }^{23}$ Там же. Л. 165-165 об.

24 Там же. Л. 391-391 об.

25 Там же. Кн. 203. Л. 153 об.-154.

${ }^{26}$ Там же. Л. 206-206 об.

${ }^{27}$ Там же. Л. 368-368 об.

${ }^{28}$ Там же. Кн. 204. Л. 36 об.-37.

${ }^{29}$ Там же. Л. 212 об.-213.

${ }^{30}$ Там же. Л. 253-253 об.

31 Там же. Кн. 205. Л. 16 об.-17.

32 Там же. Л. 51 об.-52.

33 Там же. Л. 139 об.-140.

34 Там же. Л. 148 об.-149.

35 Там же. Л. 153 об.

36 Там же. Л. 278 об.-279. У Забелина ошибочно записано 23 марта [10, с. 205-206].

37 Там же. Л. 402 об.-403 об.

38 Там же. Л. 404 об.

39 Там же. Л. 439-439 об.

40 Там же. Л. 455-455 об.

${ }^{41}$ Там же. Л. 459 об.- 460.

42 Там же. Кн. 206. Л. 187-188.

${ }^{43}$ Там же. Л. 215-215 об.

44 Там же. Л. 231 об.-232 об.

45 Там же. Л. 232 об.

46 Там же. Л. 348-348 об.

${ }^{47}$ Там же. Л. 505 об.-506.

48 Там же. Кн. 207. Л. 136 об.-137.

${ }^{49}$ Там же. Л. 159-159 об.

50 Там же. Л. 292 об.-293.

51 Там же. Л. 440-440 об.

52 Там же. Л. 477 об.-478.

${ }^{53}$ Там же. Л. 506-506 об.

\section{СПИСОК ЛИТЕРАТУРЫ}

1. Акты Московского государства, изданные Императорской Академией наук : в 3 т. Т. 1. Разрядный приказ. Московский стол. 1571-1634. - СПб. : Тип. Имп. Акад. наук, 1894. - 766 с.

2. Антонов, А. В. К начальной истории Нижегородского ополчения // Историко-археографические исследования: Россия XV - начала XVII века / А. В. Антонов. - М. : Древлехранилище, 2013. C. 264-336.

3. Барсуков, А. П. Род Шереметевых / А. П. Барсуков. - СПб. : Тип. М. М. Стасюлевича, 1882. Кн. 2. $-531 \mathrm{c}$.

4. Белокуров, С. А. Разрядные записи за Смутное время (7113-7121 гг.) / С. А. Белокуров. - М. : Имп. о-во истории и древностей рос. при Моск. унте, 1907. - XXVIII, $311 \mathrm{c}$.

5. Булычев, А. А. История одной политической кампании XVII века: законодательные акты второй половины 1620-х годов о запрете свободного 
распространения «литовских» печатных и рукописных книг в России / А. А. Булычев. - М. : Языки славянской культуры, 2004. - 144 с.

6. Гераклитов, А. А. История Саратовского края в XVI-XVIII вв. / А. А. Гераклитов. - Саратов : Друкарь ; М. : Изд-во В.З. Яксанова, 1923. - 375 + III с.

7. Гераклитов, А. А. Список саратовских и царицынских воевод XVII в. / А. А. Гераклитов // Тр. СУАК. Вып. 30. - Саратов, 1913. - С. 61-82.

8. Дворцовые разряды, по высочайшему повелению изданные II-м отделением Собственной Его Императорскаго Величества канцелярии. Т. 1. 1612-1628. - СПб. : Тип. ІІ отд-ния Собственной Его Императорского Величества канцелярии, 1850. - XV с., 912 стб.

9. Документы Печатного приказа (16131615 гг.) / сост. С. Б. Веселовский, подг. к печ. Н. К. Ткачева, отв. ред. Б. В. Левшин. - М. : Наука, 1994. -479 c.

10. Забелин, И. Е. Дополнения к Дворцовым разрядам, по поручению графа Д.Н. Блудова, собранные из книг и столбцов прежде бывших Дворцовых приказов архива Оружейной палаты Ив. Забелиным (1613-1634 гг.). Ч. 1 / И. Е. Забелин. - М. : Тип. II отд-ния Собственной Его Императорского Величества канцелярии, 1882. - XV с., 912 стб.

11. Записная книга Московского стола 1626, мая 5 - 1627, августа 31 / по инициативе кн. Г. Д. Хилкова // Русская историческая библиотека. - Т. IX. СПб. : Тип. М-ва внутренних дел, 1884. - С. 385-524.

12. Кабанов, А. Ю. Нижегородский дворянин Мисюрь Иванович Соловцов - забытый герой Смуты / А. Ю. Кабанов // Мининские чтения : сб. науч. тр. по истории Смутного времени в России начала XVII века : в память 400-летия Нижегородского Подвига. - Н. Новгород : Кварц, 2012. - С. 142-151.

13. Кабанов, А. Ю. Мисюрь Иванович Соловцов // Смутное время начала XVII века: судьбы участников / А. Ю. Кабанов, Я. Н. Рабинович. - Иваново : Издатель Епишева О. В., 2015. - С. 35-50.

14. Книга сеунчей 1613-1619 гг. / А. Л. Станиславский, С. П. Мордовина // Памятники истории Восточной Европы = Monumenta historica res gestas Europae Orientalis illustrantia: источники XVXVII вв. - Т. 1. - М. ; Варшава : Археографический центр, 1995. - С. 11-98.

15. Книги разрядные по официальным оных спискам изданныя с высочайшаго соизволения II-м отделением Собственной Его Императорскаго Величества канцелярии. - СПб. : Тип. II отд-ния Собственной Его Императорскаго Величества канцелярии, 1853. - Т. 1. - XV, II с., 1380 стб.

16. Книги разрядные по официальным оных спискам изданныя с высочайшаго соизволения II-м отделением Собственной Его Императорскаго Величества канцелярии. - СПб. : Тип. IІ отд-ния
Собственной Его Императорскаго Величества канцелярии, 1855. - Т. 2. - VI, IX 1398 стб.

17. Малов, А. В. «А пожаловал Государь их за службу»: тканное жалованье ратным людям в 16131621 гг. (номенклатура и цены) / А. В. Малов // Торговля, купечество и таможенное дело в России в XVI-XIX вв. : сб. материалов Четвертой междунар. науч. конф., г. Нижний Новгород, 28-30 сент. 2017 г. Н. Новгород : ИП Якушов Ю. И., 2018. - С. 34-52.

18. Малов, А. В. «Выход» и «выходцы» на завершающем этапе Смуты (1613-1619): определение терминологических границ (по данным расходных книг Казенного приказа) / А. В. Малов // Смутное время: итоги и уроки : сб. материалов второй Всеpoc. науч. конф., г. Иваново, Кохма, Шуя, 20-22 апр. 2012 г. / отв. ред. канд. ист. наук А. Ю. Кабанов. Иваново : Изд-во «Иваново», 2012. - С. 157-195.

19. Малов, А. В. Головы и атаманы, сотники и есаулы: Вопросы типологии чинов и смыслового содержания терминов / А. В. Малов // Древняя Русь. Вопросы медиевистики. -2017. - № 3 (69). - С. 78-79.

20. Малов, А. В. Головы и сотники московских стрельцов при отражении вторжения войск королевича Владислава в 1617-1618 гг. / А. В. Малов // Русь, Россия: Средневековье и Новое время. Вып. 5 : Пятые чтения памяти академика РАН Л.В. Милова : материалы к междунар. науч. конф., г. Москва, 910 нояб. 2017 г.-М. : Изд-во МГУ, 2017.-С. 615-623.

21. Малов, А. В. Приезды в Москву березовских служилых людей на выходе России из Смуты. 1613-1619 гг. : (По данным приходо-расходных книг Казенного приказа) // Меншиковские чтения - 2015 : материалы Российской научной конференции, г. Берёзово (Ханты-Мансийский автономный округ Югра), 27-29 нояб. 2015 г. / отв. ред. П. А. Кротов. СПб. : XVIII век, 2015. - Вып. 10. - С. 157-184.

22. Малов, А. В. Оружейные мастера в освобожденной Москве : материалы к просопографии по данным расходных книг Казенного приказа. Ч. 1. 7122-й(1613/14)-7127-й (1618/19) гг. / А. В. Малов // Материалы и исследования. Музеи Московского Кремля. Вып. 28. Оружейное собрание Музеев Кремля. Памятники, история, проблемы изучения. - М. : ФГБУК «Государственный историко-культурный музей-заповедник "Московский Кремль"», 2018. - С. 42-65.

23. Малов, А. В. Пушкарского чина люди по данным расходных книг Казенного приказа в завершающий период Смутного времени (1613-1619 гг.) / А. В. Малов // История военного дела: исследования и источники. 2016. Спец. вып. VI. Русский «бог войны»: исследования и источники по истории отечественной артиллерии. Ч. ІІ. - С. 159-217. - Электрон. текстовые дан. - Режим доступа: http:// www.milhist.info/2016/05/20/malov (дата обращения: 20.05.2016). - Загл. с экрана. 
24. Описание Грамот Коллегии экономии. Т. 1 : А-И / подг. А. В. Антонов. - М. : Древлехранилище, 2016. - 1192 с.

25. Осадный список 1618 г. / сост. Ю. В. Анхимюк, А. П. Павлов // Памятники истории Восточной Европы. Источники XV-XVII вв. T. VIII. - M. ; Варшава : Древлехранилище, 2009. - 683 с.

26. «Подлинные» боярские списки 16261633 годов : сб. док. / сост. Е. Н. Горбатов. - М. : Древлехранилище, 2015. - 736 с.

27. Разрядная книга 1637/38 года / отв. ред. В. И. Буганов ; сост.: В. И. Буганов, Л. Ф. Кузмина, А. П. Богданов. - М. : Ин-т истории АН СССР, 1983. - $187 \mathrm{c}$.

28. Рыбалко, Н. В. Дьяческая служба в Царицыне в конце XVI - XVII веке / Н. В. Рыбалко // Стрежень : науч. ежегодник. Вып. 5. - Волгоград : Изд-во ВолГУ, 2006. - С. 384-388.

29. Рыбалко, Н. В. Российская приказная бюрократия в Смутное время / Н. В. Рыбалко. - М. : МБА : Квадрига, 2011.-657 с.

30. Рыбалко, Н. В. Управление «понизовыми городами» в период междуцарствия (1610-1613 годы) / Н. В. Рыбалко // Известия Саратовского университета. Новая серия. Серия История. Международные отношения. - Т. 13, вып. 4. -2013. - С. 5-11.

31. «Сметный список» военных сил России 1651 г. // Дворянство России и его крепостные крестьяне. XVII - первая половина XVIII в. / отв. ред. Е. И. Индова, сост. Я. Е. Водарский, О. А. Шватченко. - М. : [б. и.], 1989. - С. 8-33.

32. Сметный список, сколько в Московском государстве служилых людей. 7139 г. / сост. И. Беляев // Временник императорского Общества Истории и Древностей Российских. Кн. 4. - М. : Университетская типография, 1849. - С. 18-51.

33. Смутное время Московского государства. 1604-1613 гг. : материалы, изд. Имп. о-вом истории и древностей рос. при Моск. ун-те. Вып. 2 : Акты времени правления царя Василия Шуйского (1606 г. 19 мая - 17 июля 1610 г.) / собрал и редактировал А. М. Гневушев. - М. : Имп. о-во истории и древностей рос. при Моск. ун-те, 1918. - 421 с.

34. Сташевский, Е. Д. Смета военных сил Московского государства на 1632 г. / Е. Д. Сташевский // Военно-исторический вестник. - 1910. № 9-10. - С. 49-85.

35. Тюменцев, И. О. Смутное время в России начала XVII столетия: Движение Лжедмитрия II / И. О. Тюменцев. - М. : Наука, 2008. - 692 с.

36. Тюменцев, И. О. Царицынская крепость в XVII в. / И. О. Тюменцев // Стрежень : науч. ежегодник. Вып. 2 / под ред. М. М. Загорулько. - Волгоград : Изд-во ВолГУ, 2001. - С. 183-195.

37. Тюменцев, И. О. Начало Царицына: гипотезы и факты / И. О. Тюменцев // Стрежень : науч. ежегодник. Вып. 1. - Волгоград : Изд-во ВолГУ, 2000. - C. 132-147.

38. Шепелев, И. С. Классовая борьба в Русском государстве и ее особенности в период польско-литовской и шведской интервенции // Труды по истории России в начале XVII столетия : в 2 т. Т. 1 / И. С. Шепелев; общ. ред. и коммент. И. О. Тюменцев, А. Л. Клейтман ; предисл. Н. К. Сергеев, вступ. ст. И. О. Тюменцев. - Волгоград : Перемена, 2012. - С. $15-48$.

39. Шепелев, И. С. Освободительная и классовая борьба в Русском государстве в 1608-1610 гг. : монография // Труды по истории России в начале XVII столетия: в 2 т. Т. 2 / И. С. Шепелев; общ. ред. и коммент. И. О. Тюменцев, А. Л. Клейтман ; предисл. Н. К. Сергеев, вступ. ст. И. О. Тюменцев. Волгоград : Перемена, 2012. - 508 c.

40. Andrusiewicz, A. Samozwaniec i Maryna Mniszech / A. Andrusiewicz. - Warszawa : Świat Książki z o. o., 2009. -528 s. + 16 ill.

\section{REFERENCES}

1. Akty Moskovskogo gosudarstva, izdannye Imperatorskoy Akademiey nauk: v 3 t. T. 1. Razryadnyy prikaz. Moskovskiy stol. 1571-1634 [Moscow State Acts Issued by the Imperial Academy of Sciences. In 3 vols. Vol.1. Order-in-charge Prikaz. Moscow Stol. 1571-1634]. Saint Petersburg, Typografiya ImperatorskoyAkademii nauk, 1894. 766 p.

2. Antonov A.V. K nachalnoy istorii Nizhegorodskogo opolcheniya [To the Initial History of the Nizhny Novgorod Militia]. Antonov A.V. Istorikoarkheograficheskie issledovaniya: Rossiya XVnachala XVII veka [Historical and Archaeological Research: Russia of the $15^{\text {th }}$ - the Early $17^{\text {th }}$ Century]. Moscow, Drevlekhranilishche Publ., 2013, pp. 264-336.

3. Barsukov A.P. Rod Sheremetevykh [Sheremetev Family]. Saint Petersburg, Typografiya M.M. Stasyulevicha, 1882. Book 2. 531 p.

4. Belokurov S.A. Razryadnye zapisi za Smutnoe vremya (7113-7121 gg.) [Charge Records of the Time of Troubles (7113-7121)]. Moscow, Izdanie Imperatorskogo obshchva istorii i drevnostey rossiyskikh pri Moskovskom universitete, 1907. XXVIII, $311 \mathrm{p}$.

5. Bulychev A.A. Istoriya odnoy politicheskoy kampanii XVII veka: zakonodatelnye akty vtoroy poloviny 1620-kh godov o zaprete svobodnogo rasprostraneniya "litovskikh» pechatnykh $i$ rukopisnykh knig $v$ Rossii [The History of One Political Campaign of the $17^{\text {th }}$ Century: Legislative Acts of the Second Half of the 1620s on the Prohibition of Free Distribution of "Lithuanian" Printed and Handwritten Books in Russia]. Moscow, Yazyki slavyanskoy kultury Publ., 2004. 144 p. 
6. Geraklitov A.A. Istoriya Saratovskogo kraya $v X V I-X V I I I v v$. [History of Saratov Region in the $16^{\text {th }}-$ $18^{\text {th }}$ c.]. Saratov, Drukar Publ., Moscow, Izd-vo V.Z. Yaksanova, 1923.375 + III p.

7. Geraklitov A.A. Spisok saratovskikh i tsaritsynskikh voevod XVII v. [List of Saratov and Tsaritsyn Voivodes of the $17^{\text {th }}$ c.]. Trudy Saratovskoy uchenoy arkhivnoy komissii. Vyp. 30 [Works of Saratov Scientific Archival Commission. Iss. 30]. Saratov, 1913, pp. 61-82.

8. Dvortsovye razryady, po vysochayshemu poveleniyu izdannye II-m otdeleniem Sobstvennoy Ego Imperatorskago Velichestva kantselyarii. T. 1. 16121628 [Palace Ranks Issued by Royal Decree by the 2nd Branch of His Own Imperial Majesty Chancery. Vol. 1. 1612-1628]. Saint Petersburg, Typografiya II otdeleniya Sobstvennoy Ego Imperatorskogo Velichestva kantselyarii, 1850. XV p., 912 col.

9. Veselovskiy S.B., Tkacheva N.K., Levshin B.V., eds. Dokumenty Pechatnogo prikaza (1613-1615 gg.) [Prikaz of the Seal Documents (16131615)]. Moscow, Nauka Publ., 1994. 479 p.

10. Zabelin I.E. Dopolneniya $k$ Dvortsovym razryadam, po porucheniyu grafa D.N. Bludova, sobrannye iz knig i stolbtsov prezhde byvshikh Dvortsovykh prikazov arkhiva Oruzheynoy palaty Iv. Zabelinym (1613-1634 gg.). Ch. 1 [Additions to the Palace Charges Collected from Books and Columns of the Former Palace Prikazes of Armoury Chamber Archive by Iv. Zabelin on Behalf of Duke D.N. Bludov (1613-1634). Part 1]. Moscow, Typografiya II otdeleniya Sobstvennoy Ego Imperatorskogo Velichestva kantselyarii, 1882. XV p., $912 \mathrm{col}$.

11. Zapisnaya kniga Moskovskogo stola 1626, maya 5 - 1627, avgusta 31 [Record Book of the Moscow Stol of 1626, May 5 - 1627, Aug 31]. Russkaya istoricheskaya biblioteka [Russian Historical Library]. Saint Petersburg, Typografiya Ministerstva vnutrennikh del, 1884, vol. IX, pp. 385-524.

12. Kabanov A.Yu. Nizhegorodskiy dvoryanin Misyur Ivanovich Solovtsov - zabytyy geroy Smuty [Nizhny Novgorod Nobleman Misyur I. Solovtsov - the Forgotten Hero of the Time of Troubles]. Mininskie chteniya: sb. nauch. tr. po istorii Smutnogo vremeni v Rossii nachala XVII v.: v pamyat 400-letiya Nizhegorodskogo Podviga [Minin Readings. Collection of Scientific Works on the History of the Time of Troubles in Russia in the Early $17^{\text {th }}$ Century. In Memory of the 400th Anniversary of the Nizhny Novgorod Feat]. Nizhny Novgorod, Kvarts Publ., 2012, pp. 142-151.

13. Kabanov A. Yu. Misyur Ivanovich Solovtsov [Misyur I. Solovtsov]. Kabanov A.Yu., Rabinovich Ya.N. Smutnoe vremya nachala XVII veka: sudby uchastnikov [The Time of Troubles of the Early $17^{\text {th }}$ Century: the Fate of the Participants]. Ivanovo, Izdatel Episheva O.V., 2015, pp. 35-50.
14. Stanislavskiy A.L., Mordovina S.P. Kniga seunchey 1613-1619 gg. [The Book of the Seboys of 1613-1619]. Pamyatniki istorii Vostochnoy Evropy = Monumenta historica res gestas Europae Orientalis illustrantia: istochniki XV-XVII vv. [Historical Documents of Eastern Europe. Sources of the $15^{\text {th }}$ $17^{\text {th }}$ c.]. Moscow, Warsaw, Arkheograficheskiy tsentr, 1995, vol. 1, pp. 11-98.

15. Knigi razryadnye po ofitsialnym onykh spiskam izdannyya s vysochayshago soizvoleniya II-motdeleniem Sobstvennoy Ego Imperatorskago Velichestva kantselyarii [Charge Books on Official Lists Published with the Royal Permission by the 2nd Branch of His Own Imperial Majesty Chancery]. Saint Petersburg, Typografiya II otdeleniya Sobstvennoy Ego Imperatorskago Velichestva kantselyarii, 1853, vol. 1. XV, II p., $1380 \mathrm{col}$.

16. Knigi razryadnye po ofitsialnym onykh spiskam izdannyy a vysochayshago soizvoleniya II-m otdeleniem Sobstvennoy Ego Imperatorskago Velichestva kantselyarii [Charge Books on Official Lists Published with the Royal Permission by the 2nd Branch of His Own Imperial Majesty Chancery]. Saint Petersburg, Typografiya II otdeleniya Sobstvennoy Ego Imperatorskago Velichestva kantselyarii, 1855, vol. 2. VI, IX p., $1398 \mathrm{col}$.

17. Malov A.V. «A pozhaloval Gosudar ikh za sluzhbu»: tkannoe zhalovanye ratnym lyudyam v 16131621 gg. (nomenklatura i tseny) [The Emperor Has Granted Them for Their Service»: Wages Fabrics Military People in 1613-1621 (Nomenclature and Prices)]. Torgovlya, kupechestvo i tamozhennoe delo v Rossii v XVI-XIX vv.: sb. materialov Chetvertoy mezhdunar. nauch. konf., g. Nizhniy Novgorod, 2830 sent. 2017 g. [Trade, Merchants, and Customs Business in Russia in the $16^{\text {th }}-19^{\text {th }} \mathrm{c}$. Collected Materials of the Fourth International Conference, Nizhny Novgorod, 28-30 Sep. 2017]. Nizhny Novgorod, IPYakushov Yu.I. Publ., 2018, pp. 34-52.

18. Malov A.V. «Vykhod» i «vykhodtsy» na zavershayushchem etape Smuty (1613-1619): opredelenie terminologicheskikh granits (po dannym raskhodnykh knig Kazennogo prikaza) ["Outcome" and "Descendants" at the Final Stages of the Time of Troubles (1613-1619): Determination of Terminological Borders (According to the Books of Treasury Department)]. Kabanov A.Yu., ed. Smutnoe vremya: itogi $i$ uroki: sb. materialov vtoroy Vseros. nauch. konf., g. Ivanovo, Kokhma, Shuya, 20-22 apr. 2012 g. [The Time of Troubles: Results and Lessons. Collected Materials of the Second all-Russian Scientific Conference, Ivanovo, Kokhma, Shuya, 20-22 April 2012]. Ivanovo, Izd-vo «Ivanovo», 2012, pp. 157-195.

19. Malov A.V. Golovy i atamany, sotniki i esauly: Voprosy tipologii chinov i smyslovogo soderzhaniya terminov [Colonels and Atamans, Sotniks and Esauls: 
Issues of Typology of Ranks and Meaning of Terms]. Drevnyaya Rus. Voprosy medievistiki, 2017, no. 3 (69), pp. 78-79.

20. Malov A.V. Golovy i sotniki moskovskikh streltsov pri otrazhenii vtorzheniya voysk korolevicha Vladislava v 1617-1618 gg. [Colonels and Sotniks of Moscow Streltsy while Repelling the Invasion of the Troops of Vladislav in 1617-1618]. Rus, Rossiya: Srednevekovye i Novoe vremya. Vyp. 5: Pyatye chteniya pamyati akademika RAN L.V. Milova: materialy k mezhdunar. nauch. konf., g. Moskva, 910 noyab. $2017 \mathrm{~g}$. [Rus and Russia: Medieval and New Time. Iss. 5: Fifth Readings in Memory of RAS Academician L.V. Milov. Materials for the International Scientific Conference. Moscow, 9-10 Nov. 2017]. Moscow, Izd-vo MGU, 2017, pp. 615-623.

21. Malov A.V. Priezdy v Moskvu berezovskikh sluzhilykh lyudey na vykhode Rossii iz Smuty. 16131619 gg. (Po dannym prikhodo-raskhodnykh knig Kazennogo prikaza) [Arrivals of Berezovo Service People to Moscow during the Russia's Exit from the Time of Troubles. 1613-1619 (According to the Data from Account Books of the Treasury Office)]. Krotov P.A., ed. Menshikovskie chteniya-2015: materialy Rossiyskoy nauchnoy konferentsii, g. Beryozovo (Khanty-Mansiyskiy avtonomnyy okrug Yugra), 27-29 noyab. 2015 g. [Menshikov Readings 2015: Materials of the Russian Scientific Conference, Berezovo (Khanty-Mansiysk Autonomous Okrug Yugra), 27-29 Nov. 2015]. Saint Petersburg, XVIII vek Publ., 2015, iss. 10, pp. 157-184.

22. Malov A.V. Oruzheynye mastera v osvobozhdennoy Moskve: materialy k prosopografii po dannym raskhodnykh knig Kazennogo prikaza. Ch. 1. 7122-y(1613/14)-7127-y(1618/19) gg. [Gunmen in the Liberated Moscow: Materials for the Prosopography According to Account Books of the Treasury Office. Part 1.7122(1613/14)-7127(1618/19)]. Materialy i issledovaniya. Muzei Moskovskogo Kremlya. Vyp. 28. Oruzheynoe sobranie Muzeev Kremlya. Pamyatniki, istoriya, problemy izucheniya [Materials and Research. Moscow Kremlin Museums. Iss. 28. The Armoury Collection of the Kremlin Museums. Monuments, History, Problems of Studying]. Moscow, FGBUK "Gosudarstvennyy istoriko-kulturnyy muzey-zapovednik 'Moskovskiy Kreml"', 2018, pp. 42-65.

23. Malov A.V. Pushkarskogo china lyudi po dannym raskhodnykh knig Kazennogo prikaza $\mathrm{v}$ zavershayushchiy period Smutnogo vremeni (16131619 gg.) [Pushkarsky Rank People According to the Account Books of the Treasury Office in the Final Period of the Time of Troubles (1613-1619)]. Istoriya voennogo dela: issledovaniya i istochniki. 2016. Spetsialnyy vypusk VI. Russkiy «bog voyny»: issledovaniya $i$ istochniki po istorii otechestvennoy artillerii. Ch. II [History of Military Affairs: Research and Sources. 2016. Special Edition VI. Russian "God of War": Studies and Sources on the History of Russian Artillery. Part 2],pp. 159-217. URL: http://www.milhist.info/ 2016/05/20/malov (accessed 20 May 2016).

24. Antonov A.V., ed. Opisanie Gramot Kollegii ekonomii. T. 1: A-I [Description of Documents of the Board of Economy. Vol. 1: A-I]. Moscow, Drevlekhranilishche Publ., 2016. 1192 p.

25. Ankhimyuk Yu.V., Pavlov A.P., ed. Osadnyy spisok $1618 \mathrm{~g}$. [Siege List of 1618]. Pamyatniki istorii Vostochnoy Evropy. Istochniki XV-XVII vv. T. VIII [Documents of Eastern Europe History. Sources of the $15^{\text {th }}-17^{\text {th }} \mathrm{c}$. Vol. 8]. Moscow, Warsaw, Drevlekhranilishche Publ., 2009. 683 p.

26. Gorbatov E.N., ed. «Podlinnye» boyarskie spiski 1626-1633 godov: sb. dok. ["Original” Boyar Lists of 1626-1633. Collected Documents]. Moscow, Drevlekhranilishche Publ., 2015. 736 p.

27. Buganov V.I., Kuzmina L.F., Bogdanov A.P., eds. Razryadnaya kniga 1637/38 goda [The Charge Book of 1637-1638]. Moscow, Institut istorii AN SSSR, $1983.187 \mathrm{p}$.

28. Rybalko N.V. Dyacheskaya sluzhba v Tsaritsyne v kontse XVI - XVII veke [Clerk Service in Tsaritsyn in the Late $16^{\text {th }}-17^{\text {th }}$ Centuries]. Strezhen: nauch. ezhegodnik. Vyp. 5 [Scientific Annual "Strezhen". Iss. 5]. Volgograd, Izd-vo VolGU, 2006, pp. 384-388.

29. Rybalko N.V. Rossiyskaya prikaznaya byurokratiya v Smutnoe vremya [Russian Prikaz Bureaucracy in the Time of Troubles]. Moscow, MBA Publ., Kvadriga Publ., 2011.657 p.

30. Rybalko N.V. Upravlenie «ponizovymi gorodami» V period mezhdutsarstviya (1610-1613 gody) [Management of Towns in Low and Middle Volga Region During the Interregnum (1610-1613)]. Izvestiya Saratovskogo universiteta. Novaya seriya. Seriya Istoriya. Mezhdunarodnye otnosheniya [Izvestiya of Saratov University. New Series. Series: History. International Relations], 2013, vol. 13, iss. 4, pp. 5-11.

31. «Smetnyy spisok» voennykh sil Rossii $1651 \mathrm{~g}$. ["Estimate List" of the Russian Military Forces in 1651]. Indova E.I., Vodarskiy Ya.E., Shvatchenko O.A., eds. Dvoryanstvo Rossii i ego krepostnye krestyane. XVII pervaya polovina XVIII v. [The Nobility of Russia and Its Serfs. The $17^{\text {th }}-$ the Early $18^{\text {th }}$ c.]. Moscow, 1989, pp. 8-33.

32. Belyaev I. Smetnyy spisok, skolko v Moskovskom gosudarstve sluzhilykh lyudey. 7139 g. [Estimated List, How Many Serving People Were There in the Moscow State in 1739]. Vremennik imperatorskogo Obshchestva Istorii i Drevnostey Rossiyskikh. Kn. 4 [Annals of the Imperial Society of Russian History and Antiquities. Book. 4]. Moscow, Universitetskaya tipografiya, 1849, pp. 18-51. 
33. Gnevushev A.M., ed. Smutnoe vremya Moskovskogo gosudarstva. 1604-1613 gg.: materialy, izdannye Imperatorskim Obshchestvom istorii i drevnostey rossiyskikh pri Moskovskom universitete. Vyp. 2: Akty vremeni pravleniya tsarya Vasiliya Shuyskogo (1606 g. 19 maya - 17 iyulya 1610 g.) [The Time of Troubles of the Moscow State. 1604-1613. Materials Published by the Society of Russian History and Antiquities at Moscow University. Iss. 2: Acts of the Reign of Tsar Vasily Shuisky (1606, 19 May - 17 July, 1610)]. Moscow, Imperatorskoe obshchestvo istorii i drevnostey rossiyskikh pri Moskovskom universitete., 1918. $421 \mathrm{p}$.

34. Stashevskiy E.D. Smeta voennykh sil Moskovskogo gosudarstva na $1632 \mathrm{~g}$. [Estimates of the Military Forces of the Moscow State for 1632]. Voennoistoricheskiy vestnik, 1910, no. 9-10, pp. 49-85.

35. Tyumentsev I.O. Smutnoe vremya v Rossii nachala XVII stoletiya: Dvizhenie Lzhedmitriya II [The Time of Troubles in Russia in the Early $17^{\text {th }}$ Century: the Movement of the False-Dmitry II]. Moscow, Nauka Publ., 2008. 692 p.

36. Tyumentsev I.O. Tsaritsynskaya krepost v XVII v. [Tsaritsyn Fortress in the $\left.17^{\text {th }} \mathrm{c}.\right]$. Zagorulko M.M., ed. Strezhen: nauch. ezhegodnik.
Vyp. 2 [Scientific Annual "Strezhen". Iss. 2]. Volgograd, Izd-vo VolGU, 2001, pp. 183-195.

37. Tyumentsev I.O. Nachalo Tsaritsyna: gipotezy i fakty [The Beginning of Tsaritsyn: Hypotheses and Facts.]. Strezhen: nauch. ezhegodnik. Vyp. 1 [Scientific Annual "Strezhen". Iss. 1]. Volgograd, Izd-vo VolGU, 2000, pp. 132-147.

38. Shepelev I.S. Klassovaya borba v Russkom gosudarstve i ee osobennosti v period polskolitovskoy i shvedskoy interventsii [Class Struggle in the Russian State and Its Features During the PolishLithuanian and Swedish Intervention]. Shepelev I.S. Trudy po istorii Rossii v nachale XVII stoletiya: $v 2 t$. T. 1 [Works on the History of Russia in the Early $17^{\text {th }}$ Century: In 2 vols. Vol. 1]. Volgorad, Peremena Publ., 2012, pp. 15-48.

39. Shepelev I.S. Osvoboditelnaya i klassovaya borba v Russkom gosudarstve v 1608-1610 gg.: monografiya [Liberation and Class Struggle in the Russian State in 1608-1610. Monograph]. Shepelev I.S. Trudy po istorii Rossii v nachale XVII stoletiya: $v 2 t$. T. 2 [Works on the History of Russia in the Early $17^{\text {th }}$ Century: In 2 vols. Vol. 2]. Volgorad, Peremena Publ., 2012. 508 p.

40. Andrusiewicz A. Samozwaniec i Maryna Mniszech. Warsaw, Świat Książki zo. o., 2009.528 p. + 16ill.

\section{Information about the Author}

Alexandr V. Malov, Candidate of Sciences (History), Senior Researcher, Center for Military History of Russia, Institute of Russian History, RAS, Dmitry Ulyanov St., 19, 117292 Moscow, Russian Federation, Supilluliuma@yandex.ru, https://orcid.org/0000-0002-5150-2671

\section{Информация об авторе}

Александр Витальевич Малов, кандидат исторических наук, старший научный сотрудник Центра военной истории России, Институт российской истории РАН, ул. Дмитрия Ульянова, 19, 117292 г. Москва, Российская Федерация, Supilluliuma@yandex.ru, https://orcid.org/0000-0002-5150-2671 